\title{
GROWTH RATE AND MOLAR GROWTH YIELD OF ESCHERICHIA COLI ADSORBED ON AN ANION-EXCHANGE RESIN
}

\author{
REIKO HATTORI AND TSUTOMU HATTORI \\ Institute for Agricultural Research, Tohoku University, Sendai
}

(Received March 18, 1981)

\begin{abstract}
Using a rapid continuous flow system $(D=1)$, growth rates and molar growth yields of free and adsorbed cells of Escherichia coli were determined with glucose as a limiting substrate. In this system, free cells were continuously removed and a steady state in cell or substrate concentration in the liquid phase of culture was realized by the growth of adsorbed cells. Growth constants of free cells, $\mu$ and $Y$, were obtained from a washout curve of free cells and a corresponding curve of increase of a substrate. Growth constants of adsorbed cells, $\mu_{\mathrm{a}}$ and $Y_{\mathrm{a}}$, were obtained from steady state concentrations of cell and substrate in the liquid phase of culture during cultivation of adsorbed cells.

The growth rate of adsorbed cells depended both on substrate concentration and the amount of adsorbed cells. Saturation constants for growth, $K_{\mathrm{s}}$, with glucose as a substrate were extremely high and they also depended on the amount of adsorbed cells. The maximal growth rate and the molar growth yield of adsorbed cells were much higher than those of free cells.
\end{abstract}

In studying bacterial growth in a heterogeneous system, a problem is how to estimate the growth constants of adsorbed cells distinguishing them from those of free cells and there have been comparatively few reports in this direction. LARSEN and Dimmick (1) showed that the growth of Serratia marcescens was much accelerated on a glass surface. PANIKOv et al. (2) proposed a kinetic model for the growth of a yeast in a sand column, making a distinction between free and adsorbed states.

Previously, one of the authors showed that the growth rate of adsorbed cells and that of free cells could be estimated separately in a rapid continuous flow culture with a dilution rate larger than a critical one $\left(D<D_{\mathrm{c}}\right)$ by the constant removal of free cells from the system and showed that the growth rate of Escherichia coli and Bacillus subtilis or the spore formation rate of B. subtilis was much accelerated 
by adsorption on an anion-exchange resin, Dowex 1-X4, 100-200 mesh, in chloride form $(3,4)$. The rapid continuous flow system in our studies differs in two points from the usual steady state continuous flow system: at first, a steady state is realized mainly by the growth of adsorbed organisms from the surface of an adsorbent and secondly, plenty of substrate remains in the system without being exhausted. In the present report, the growth rate and molar growth yield of E. coli was studied in relation to glucose concentration.

\section{MATERIALS AND METHODS}

Symbols and units. These were as follows unless otherwise stated.

$D$, dilution rate $\left(\mathrm{hr}^{-1}\right)$.

$D_{\mathrm{c}}$, critical dilution rate for free cells $\left(\mathrm{hr}^{-1}\right)$.

$K_{\mathrm{s}}$, saturation constant for growth with glucose as a substrate (M).

$S$, glucose concentration of culture (mM).

$\bar{S}$, steady level glucose concentration of culture (mM).

$S_{\mathrm{R}}$, glucose concentration of medium in reservoir (mM).

$X$, cell concentration in the liquid phase of culture ( $\mathrm{mg}$ dry $\mathrm{wt}^{-1} \mathrm{ml}^{-1}$ ).

$\bar{X}$, steady level cell concentration in the liquid phase of culture $\left(\mathrm{mg}\right.$ dry $\left.\mathrm{wt} \mathrm{ml}^{-1}\right)$.

$X_{\mathrm{a}}$, amount of adsorbed cells represented in terms of concentration in the liquid phase of culture (mg dry wt $\mathrm{ml}^{-1}$ ).

$Y$, molar growth yield of free cells (g dry wt (mole glucose) $\left.{ }^{-1}\right)$.

$Y_{\mathrm{a}}$, molar growth yield of adsorbed cells (g dry wt (mole glucose) $)^{-1}$ ).

$\mu$, specific growth rate of free cells $\left(\mathrm{hr}^{-1}\right)$.

$\mu_{\mathrm{a}}$, specific growth rate of adsorbed cells $\left(\mathrm{hr}^{-1}\right)$.

$\mu^{\mathrm{max}}$, theoretical maximum of $\mu\left(\mathrm{hr}^{-1}\right)$.

$\mu_{\mathrm{a}}^{\max }$, theoretical maximum of $\mu_{\mathrm{a}}\left(\mathrm{hr}^{-1}\right)$.

Organism. Cells of E. coli Yamaguchi strain were preincubated for $16.5 \mathrm{hr}$ with shaking at $30^{\circ}$ in a growth medium and, after being harvested by centrifugation, suspended in a small volume of the medium (1-3 mg dry weight of cells $/ \mathrm{ml}$ ).

Medium. The composition of growth medium was the same as in the previous report (3) except that various amounts of filter-sterilized glucose solution were added aseptically.

Resin. An anion-exchange resin, Dowex 1-X4, 50-100 mesh (ca. 0.15$0.30 \mathrm{~mm}$ in diameter) in chloride form was used.

Preparation of adsorbed cells. Concentrated cell suspension in growth medium was added to resin $(2.5-5 \mathrm{ml}$ suspension $/ 10 \mathrm{~g}$ wet weight of resin), mixed and kept at $30^{\circ}$ for $10 \mathrm{~min}$. Resin particles with adsorbed cells were gently washed several times with prewarmed growth medium $\left(30^{\circ}\right)$ to remove nonadsorbed cells. In each experiment, the amount of washed cells was subtracted from that of added ones, the amount of adsorbed cells being found to be about $0.3 \mathrm{mg}$ dry weight of cells/g wet weight of resin. From the adsorption isotherm 
of the organism by the resin which will be reported elswhere, it was also found that the maximum adsorption was the same as above in phosphate buffer of comparable ionic strength as the growth medium.

Culture apparatus. Sterilized growth medium was induced by a Watson Marlow H. R. flow inducer (type MHRE 7) into a $500 \mathrm{ml}$ flask with $360 \mathrm{ml}$ working volume, and passed out through a side arm. The flask containing free or adsorbed cells was kept in a $30^{\circ}$ water bath with gentle stir by magnetic stirrer. The speed of stirring was so adjusted that the content was mixed well but resin particles did not flow out from the vessel.

Cultivation of organism. A previous report (5) showed that it takes 1 to $2 \mathrm{hr}$ for adsorbed cells to begin growing actively on resin surface and, in this experiment, adsorbed cells were kept at least $1.5 \mathrm{hr}$ in a growth medium $\left(30^{\circ}\right)$ before starting continuous cultivation in the same medium $(D=1)$. Regarding free cells in control experiments, since rapid washing out was expected at $D=1$, cells were at first heavily inoculated, kept for at least $1 \mathrm{hr}$ in a growth medium at a low dilution rate and then incubated at a high dilution rate $(D=1)$. Cell concentration in the effluent was determined every $10 \mathrm{~min}$ by turbidimetry (O.D. at $530 \mathrm{~nm}$ ) and converted into dry weight.

Glucose consumption. A small portion of effluent was sampled every $20 \mathrm{~min}$, filtered immediately by a Millipore filter $(0.3 \mu \mathrm{m})$ or rapidly centrifuged to remove organisms, and kept at $4^{\circ}$. Soon afterwards, glucose concentration of each sample and that of medium in the reservoir was determined by the anthrone reaction and glucose consumption was obtained as the difference between the two values.

\section{RESULTS}

Growth of adsorbed cells in a rapid continuous flow system and the theory for obtaining their growth constants

When adsorbed cells were incubated in a rapid continuous flow system $(D=1)$, cell concentration in the effluent increased stepwise to a steady level (Fig. 1), similarly to previous reports $(3,4)$. When cell concentration reached a steady level, glucose concentration did likewise (Fig. 1). Since the dilution rate in this experiment exceeds a critical dilution rate for free cells, free cells are continuously washed out from the system and, as previously depicted $(3,6)$, the steady state in cell or substrate concentration in the liquid phase of culture is mainly attributable to the growth of adsorbed cells and the constant detatchment of their daughter cells from resin surface.

During the growth of adsorbed cells, the change in cell or substrate concentration in the liquid phase of culture is shown as follows $(2,3)$ :

$$
\begin{aligned}
& \frac{\mathrm{d} X}{\mathrm{~d} t}=\mu X+\mu_{\mathrm{a}} X_{\mathrm{a}}-D X \\
& \frac{\mathrm{d} S}{\mathrm{~d} t}=D S_{\mathrm{R}}-D S-\frac{\mu X}{Y}-\frac{\mu_{\mathrm{a}} X_{\mathrm{a}}}{Y_{\mathrm{a}}} .
\end{aligned}
$$




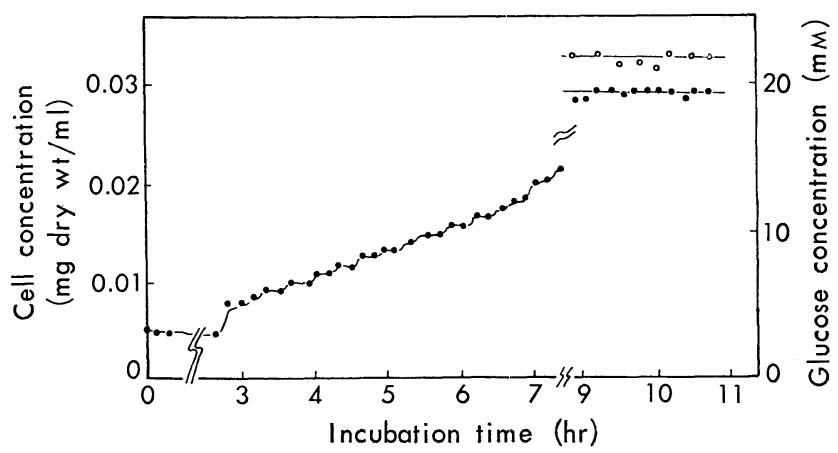

Fig. 1. Change in cell and substrate concentrations in the liquid part of culture during growth of adsorbed cells.

- cell concentration; $\bigcirc$, glucose concentration.

Applying the steady state condition, $\mathrm{d} X / \mathrm{d} t=0$ or $\mathrm{d} S / \mathrm{d} t=0$, to equation (1) or (2), we have:

or

$$
\begin{gathered}
\mu_{\mathrm{a}}=\frac{(D-\mu) X}{X_{\mathrm{a}}} \\
Y_{\mathrm{a}}=\frac{Y(D-\mu) X}{Y D\left(S_{\mathrm{R}}-S\right)-\mu X} \\
\frac{1}{Y_{\mathrm{a}}}=\frac{D}{D-\mu} \frac{\left(S_{\mathrm{R}}-S\right)}{X}-\frac{\mu}{D-\mu} \frac{1}{Y} .
\end{gathered}
$$

Growth constants of adsorbed cells, $\mu_{\mathrm{a}}$ and $Y_{\mathrm{a}}$, can be calculated from the above equations if those of free cells, $\mu$ and $Y$, under a washout condition are known.

Growth rate of free cells under a washout condition

In studying the chemostat growth of slow-growing bacteria the steady state of which was hardly realized, JANNASCH determined their growth rates from the slope of logarithmic plots of washout curves (7). The growth rate of free cells under a washout condition $(D=1)$ was obtained as previously $(3,4)$ according to his method. Results of several washing out experiments are shown in Fig. 2. Each slope is not exactly identical and tends to decrease during incubation, which may be interpreted, on the one hand, by bacterial adsorption and growth on the surface of the glass container as pointed out by HERBERT et al. (8) and, on the other hand, by a change in growth rate in the course of washing out, as will be discussed later. Values of $\mu$ were obtained from the intermediate period of washout curves (Table 1), and the mean value, 0.5, was used for calculation of $\mu_{\mathrm{a}}$ and $Y_{\mathrm{a}}$.

Molar growth yield of free cells under a washout condition

At a dilution rate lower than a critical one $\left(D<D_{\mathrm{c}}\right)$, both cell and substrate 


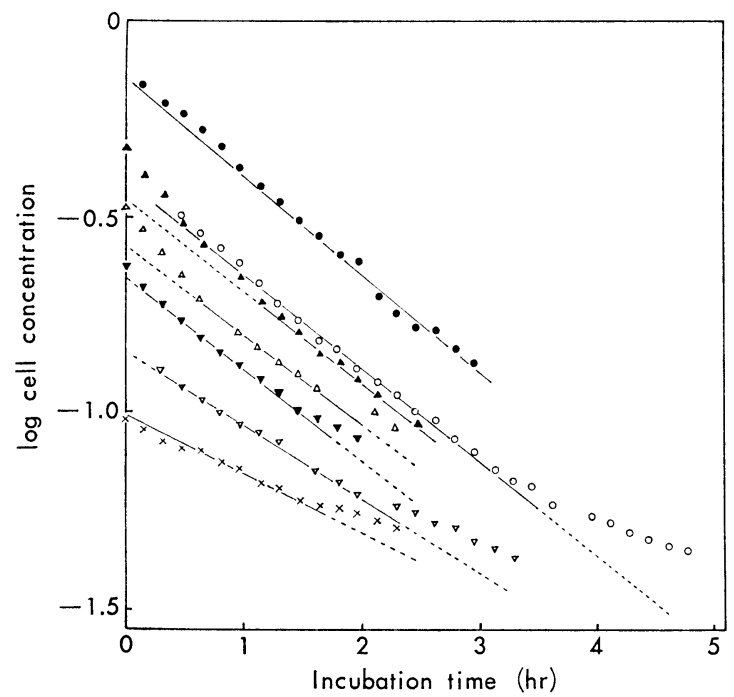

Fig. 2. Change in logarithm of cell concentration (mg dry $\left.\mathrm{wt} \mathrm{ml}^{-1}\right)$ during washout of free cells.

Glucose concentration in inflowing medium with each experiment is shown in

Table 1 . $\odot$, exp. $1 ; \bigcirc$, exp. $2 ; \Delta$, exp. $3 ; \Delta$, exp. $4 ; \nabla$, exp. $5 ; \nabla$, exp. $6 ; \times$, exp. 7 .

Table 1. Growth rate of free cells in a washout condition.

\begin{tabular}{cccc}
\hline Experiment No. & $\mathrm{A}^{a}$ & $\begin{array}{c}\mu^{b} \\
\left(\mathrm{hr}^{-1}\right)\end{array}$ & $\begin{array}{c}\text { Glucose concentration } \\
\text { of medium in reservoir } \\
(\mathrm{g} / l)\end{array}$ \\
\hline 1 & -0.245 & 0.435 & 2 \\
2 & -0.232 & 0.466 & 5 \\
3 & -0.222 & 0.489 & 5 \\
4 & -0.245 & 0.435 & 5 \\
5 & -0.230 & 0.471 & 1 \\
6 & -0.148 & 0.659 & 2 \\
7 & -0.190 & 0.563 & 5 \\
Mean & -0.216 & 0.502 & \\
\hline
\end{tabular}

Washout experiment was carried out at $D=1$.

a Slope of washout curve represented as $A=\log e(\mu-D)$ in the following equation: $\log X=\log e(\mu-D) t+\log X_{0}$.

$b$ Growth rate of free cells calculated from the value of $A$ with each experiment.

concentrations in free cell culture reach steady levels and, according to the theory of continuous culture (8), the apparent molar growth yield of free cells can be obtained by the following equation:

$$
Y=\frac{X}{S_{\mathrm{R}}-S}
$$

When $D>D_{\text {c }}$, the cell concentration decreased rapidly and in turn, substrate concentration increased (Fig. 3). The apparent molar growth yield of free cells under 


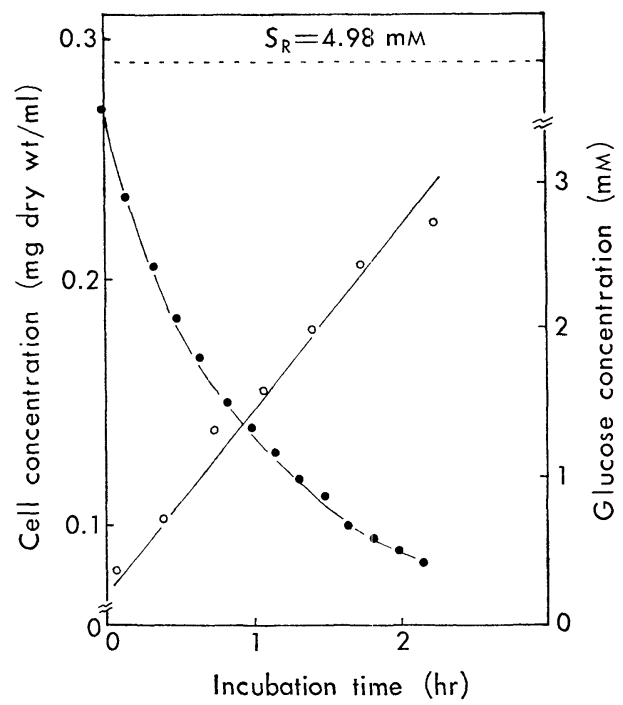

Fig. 3. Change in cell or substrate concentration during washout of free cells.

-, cell concentration; $\bigcirc$, glucose concentration.

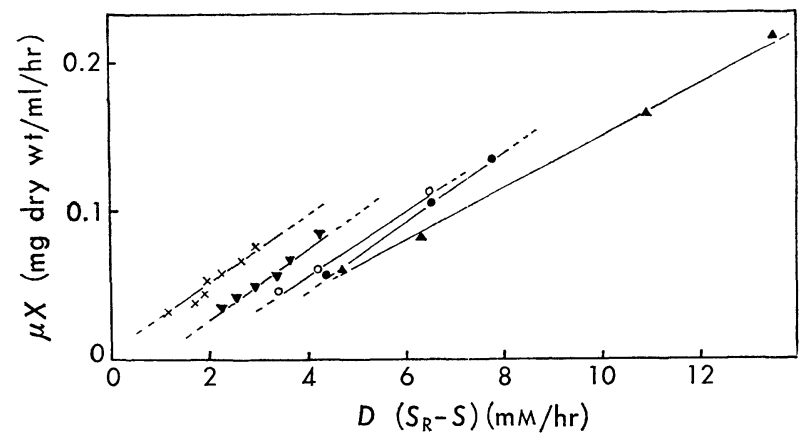

Fig. 4. Relationship between growth and substrate consumption within a short interval during washout of free cells.

Glucose concentration in inflowing medium with each experiment is shown in Table 1. ๑, exp. $1 ;$ ○, exp. 2 ; $\Delta$, exp. $3 ; \nabla$, exp. $5 ; \times$, exp. 7 .

such a washout condition may be expressed by the ratio of growth to substrate consumption within a short interval during washout:

$$
\begin{gathered}
\mathrm{d} X=\mu X \mathrm{~d} t \\
\mathrm{~d} S=D\left(S_{\mathrm{R}}-S\right) \mathrm{d} t .
\end{gathered}
$$

From equations (6) and (7),

$$
\frac{\mathrm{d} X}{\mathrm{~d} S}=\frac{\mu X}{D\left(S_{\mathrm{R}}-S\right)}
$$


Table 2. Molar growth yield of free cells in a washout condition.

\begin{tabular}{ccccc}
\hline Experiment & $\begin{array}{c}S_{\mathrm{R}}{ }^{a} \\
(\mathrm{mM})\end{array}$ & $\begin{array}{c}\mu \\
\left(\mathrm{hr}^{-1}\right)\end{array}$ & $\begin{array}{c}Y^{b} \\
(\mathrm{~g} \text { dry wt/mole glucose })\end{array}$ \\
\hline 5 & 4.98 & 0.472 & 22.0 & 26.8 \\
1 & 9.90 & 0.435 & 22.2 & 26.0 \\
6 & 10.10 & 0.659 & 22.4 & 16.8 \\
2 & 21.90 & 0.466 & 18.0 & 18.2 \\
4 & 22.70 & 0.435 & 22.0 & 25.4 \\
\hline
\end{tabular}

As the ratio of growth to consumption within a short interval was the same during washout of free cells, the molar growth yield of free cells was given by, $Y=\mu X / D\left(S_{\mathrm{R}}-S\right)$.

$a$ Glucose concentration of medium in reservoir.

$b$ Molar growth yield calculated using $\mu$ with corresponding washout curve.

$c$ Molar growth yield calculated using mean growth rate, $\bar{\mu}=0.5$.

In the equation (8), $X$ and $S$ are functions of incubation time. When $\mu X$ was plotted against $D\left(S_{\mathrm{R}}-S\right)$ with the corresponding interval, a linear relationship was obtained, though the slopes of individual curves were slightly different from each other (Fig. 4). Therefore it was concluded that the apparent molar growth yield of free cells was constant during washout. Values of $Y$ thus obtained with several experiments are shown in Table 2. The apparent molar growth yield of free cells obtained in a steady state $(D=0.58)$, with the same organism and the same growth medium with $1 \mathrm{~g} / \mathrm{l}$ of glucose was 31.46 . It is noticeable that yields under a washout condition are much lower than in a steady state.

\section{Growth rate of adsorbed cells in relation to substrate concentration}

In a rapid continuous flow culture of adsorbed cells, a steady level cell concentration, $\bar{X}$, with the amount of adsorbed cells used, $X_{\mathrm{a}}$, depended on substrate

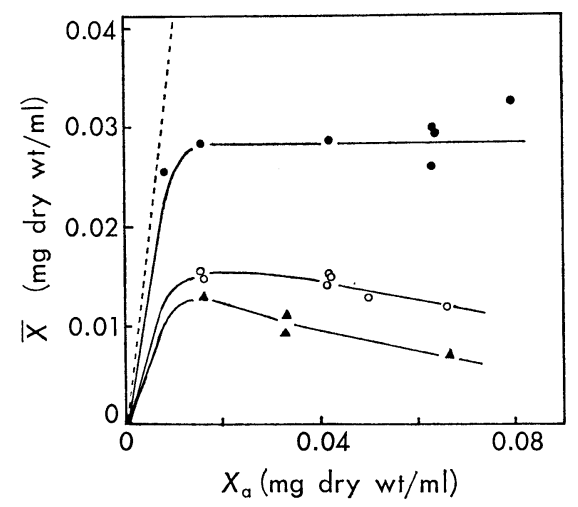

Fig. 5. Steady level cell concentration in liquid phase, $\bar{X}$, in relation to the amount of adsorbed cells, $X_{\mathrm{a}}$, during growth of adsorbed cells.

Glucose concentrations in inflowing medium are: $\bullet, 5 \mathrm{~g} / l ; 0,2 \mathrm{~g} / l ; \Delta, 1 \mathrm{~g} / l$. A dotted line represents, $\bar{X}=\mu_{\mathrm{a}}^{\max } X_{\mathrm{a}} /(D-\mu)$, where $D=1, \mu=0.5, \mu_{\mathrm{a}}^{\max }=2.0$. See the text. 


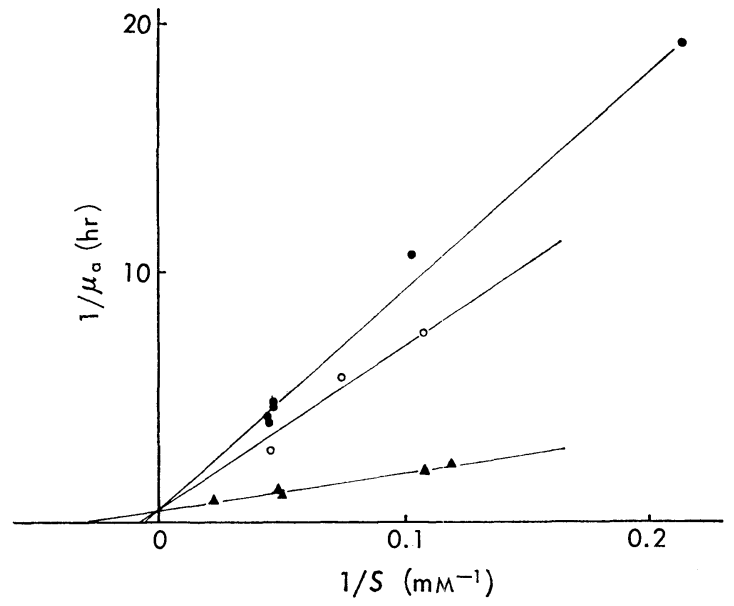

Fig. 6. Reciprocal plots of $\mu_{\mathrm{a}}$ against substrate concentration. The amount of resin used are: ๑, 75-95 g; ○, 50-60 g; $\Delta, 20 \mathrm{~g}$.

Table 3. Growth rate of adsorbed cells.

\begin{tabular}{|c|c|c|c|c|}
\hline $\begin{array}{c}\text { Resin } \\
(\mathrm{g})\end{array}$ & $\begin{array}{c}X^{a} \\
\text { (mg dry wt/ml) }\end{array}$ & $\begin{array}{c}X_{\mathrm{a}}{ }^{b} \\
(\mathrm{mg} \operatorname{dry} \mathrm{wt} / \mathrm{ml})\end{array}$ & $\begin{array}{c}\mu_{\mathrm{a}}^{c} \\
\left(\mathrm{hr}^{-1}\right)\end{array}$ & $\begin{array}{c}S^{d} \\
(\mathrm{mM})\end{array}$ \\
\hline 10 & 0.026 & 0.008 & 1.560 & 19.40 \\
\hline 20 & 0.0155 & 0.016 & 0.465 & 9.18 \\
\hline 20 & 0.0285 & 0.016 & 0.855 & 19.66 \\
\hline 50 & 0.014 & 0.0416 & 0.168 & 13.22 \\
\hline 60 & 0.013 & 0.050 & 0.130 & 9.20 \\
\hline 50 & 0.029 & 0.0416 & 0.348 & 22.08 \\
\hline 80 & 0.007 & 0.066 & 0.052 & 4.66 \\
\hline 80 & 0.0125 & 0.066 & 0.093 & 9.60 \\
\hline 75 & 0.026 & 0.0625 & 0.208 & 21.08 \\
\hline 95 & 0.033 & 0.0791 & 0.208 & 21.20 \\
\hline 75 & 0.030 & 0.0625 & 0.240 & 21.28 \\
\hline 75 & 0.030 & 0.0625 & 0.240 & 21.28 \\
\hline
\end{tabular}

$a \quad$ Steady level cell concentration in liquid phase.

$b$ Amount of adsorbed cells in terms of cell concentration which was obtained by dividing amount of adsorbed cells, $0.3 \mathrm{mg}$ dry $\mathrm{wt} / \mathrm{g}$ resin, by culture volume.

c Growth rate of adsorbed cells given by equation (3), for which $\mu=0.5$ and $D=1$ are used.

$d$ Steady level substrate concentration in liquid phase.

concentration (Fig. 5). From these plots and equation (3), $\mu_{\mathrm{a}}$ was calculated with each experiment (Table 3). As expected from the equation (3), $\mu_{\mathrm{a}}$ depended both on $\bar{X}$ and $X_{\mathrm{a}}$, that is, both on a steady level substrate concentration, $S$, and $X_{\mathrm{a}}$ since $\bar{X}$ was nearly proportional to $\bar{S}$. From the reciprocal plots of $\mu_{\mathrm{a}}$ against 
$\bar{S}$ (Fig. 6), $\mu_{\mathrm{a}}^{\max }$ or saturation constant for growth, $K_{\mathrm{s}}$, with adsorbed cells were obtained (Table 4). The value, $\mu_{\mathrm{a}}^{\max }$, was about $2.0 \mathrm{hr}^{-1}$ independent of $X_{\mathrm{a}}$, which was much higher than $\mu$ under a washout condition or in batch culture. It is noticeable that $K_{\mathrm{s}}$ values with adsorbed cells are extremely high and also that these values depended significantly on the amount of adsorbed cells.

\section{Molar growth yield of adsorbed cells}

From equation (4'), the apparent molar growth yield of adsorbed cells is obtainable if the relationship between $\bar{X}$ and substrate consumption, $S_{\mathrm{R}}-S$, is known. Because of the high dilution rate in this system, plenty of substrate remains without being exhausted and the value, $S_{\mathrm{R}}-S$, is very small compared to that in a usual steady state continuous culture, which makes the accurate determination of the value difficult. Therefore the ratio, $\left(S_{\mathrm{R}}-S\right) / X$, was obtained by a regression of $\bar{X}$ on $S_{\mathrm{R}}-S$ (Fig. 7) and $Y_{\mathrm{a}}$ was calculated to be 50.25 or 65.35 when $Y$ was 22

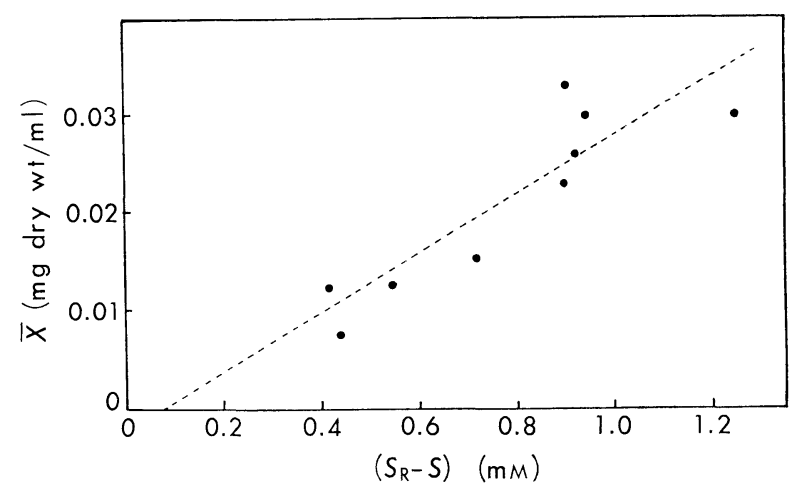

Fig. 7. Steady level cell concentration, $\bar{X}$, in relation to glucose consumption, $S_{\mathrm{R}}-S$. A dotted line is a regression of $X$ on $S_{\mathrm{R}}-S . \quad \bar{X}=-0.0026+0.0306\left(S_{\mathrm{R}}-S\right), r=0.886$.

or 20, respectively. The value, $S_{\mathrm{R}}-S$, at $X=0$ was $0.085 \mathrm{~mm}$ which probably reflects a maintenance requirement by the adsorbed organism (Fig. 7). It is noticeable that the molar growth yield of adsorbed cells was much higher than those of free cells both under steady state and washout conditions.

\section{DISCUSSION}

The growth constants of adsorbed cells, $\mu_{\mathrm{a}}$ and $Y_{\mathrm{a}}$, and those of free ones, $\mu$ and $Y$, can be estimated separately in a rapid continuous flow system. Values of $\mu_{\mathrm{a}}$ and $Y_{\mathrm{a}}$ can be obtained by equations (3) and (4) if $\mu$ and $Y$ are known. The problem is to obtain exact values of $\mu$ and $Y$ under a washout condition. As HERBERT et al. suggested (8), the effect of wall growth may become significant especially when $D \geqq D_{\text {c }}$. To make the effect as small as possible, estimation of 

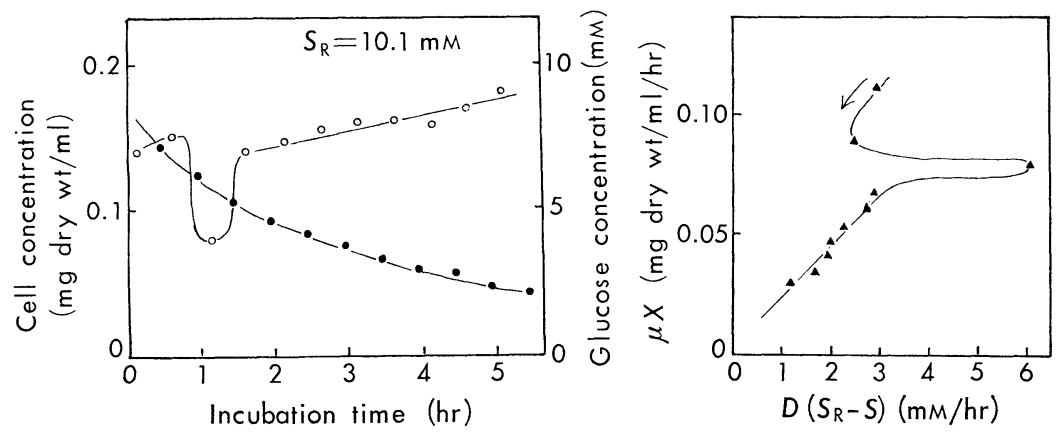

Fig. 8. Fluctuation in plots of substrate concentration or those of growth against substrate consumption within a short interval at the beginning of washout of free cells.

o, cell concentration; $\bigcirc$, substrate concentration; $\boldsymbol{\Delta}$, growth against substrate consumption within a short interval during washout. The direction of incubation time is indicated by arrow.

$\mu$ should be done in the early period of a washout experiment. On the other hand, as pointed out by TEMPEST (9), it is probable that $\mu$ does not instantaneously increase with the increase in $D$, which is suggested by the fluctuation in plots of substrate concentration or plots of growth against substrate consumption within a short interval at the beginning of washout of free cells (Fig. 8). Therefore the estimation of $\mu$ and $Y$ was made in the early period but after washout curves had been stabilized. It is notable that either $\mu$ or $Y$ thus obtained was smaller than $\mu$ obtained at a high dilution rate or $Y$ obtained at a wide range of dilution rate in a steady state continuous culture. There have been only a few reports made on bacterial growth under a washout condition (7) and further study is necessary as to cell physiology including growth rate and yield under such a condition.

In a rapid continuous flow culture, it might not be thought that the substrate becomes limited for bacterial growth, because the dilution rate is extremely high $\left(D>D_{\mathrm{c}}\right)$ and plenty of substrate remains without being exhausted. As regards free cells, this is suggested to be the case from the fact that $\mu$ is independent of substrate concentration (Table 1), while as to adsorbed cells, $\mu_{\mathrm{a}}$ is significantly dependent on substrate concentration, suggesting substrate-limited growth (Table 3 ). The situation is also suggested from Fig. 5, where a steady level cell concentration, $\bar{X}$, with the amount of adsorbed cells used, $X_{\mathrm{a}}$, increases depending on glucose concentration. From equation (3),

$$
\bar{X}=\frac{\mu_{\mathrm{a}} X_{\mathrm{a}}}{D-\mu} .
$$

Since $\mu$ is nearly constant and $X_{\mathrm{a}}$ is constant in an experiment, the maximal value of $\bar{X}$ is given at $\mu_{\mathrm{a}}=\mu_{\mathrm{a}}^{\max }$ : 
Table 4. Growth constants of adsorbed cells.

\begin{tabular}{ccc}
\hline $\begin{array}{c}\text { Resin } \\
(\mathrm{g})\end{array}$ & $\begin{array}{c}\mu_{\mathrm{a}}^{\max } \\
\left(\mathrm{hr}^{-1}\right)\end{array}$ & $\begin{array}{c}K_{\mathrm{s}} \\
(\mathrm{M})\end{array}$ \\
\hline 20 & 2.05 & $0.3 \times 10^{-1}$ \\
$50-60$ & 2.0 & $1.17 \times 10^{-1}$ \\
$75-95$ & 2.02 & $1.53 \times 10^{-1}$ \\
\hline
\end{tabular}

$$
\bar{X}^{\max }=\frac{\mu_{\mathrm{a}}^{\max } X_{\mathrm{a}}}{D-\mu} .
$$

Putting $D=1, \mu=0.5$ and $\mu_{\mathrm{a}}^{\max }=2.0$, we have:

$$
\bar{X}^{\max }=4 X_{\mathrm{a}} \text {. }
$$

Equation (11) is represented by a dotted line in Fig. 5, where $\bar{X}^{\text {max }}$ will be realized when the growth of adsorbed cells is not limited by substrate concentration. The fact that almost all the plots in Fig. 5 are below the dotted line indicates that, under these experimental conditions, the growth of adsorbed cells is strongly limited by glucose concentration. Extremely high $K_{\mathrm{s}}$ values with adsorbed cells (Table 4) also suggests substrate-limited growth.

Results in Tables 3 and 4 also show that the growth rate of adsorbed cells depends not only on substrate concentration but also on the amount of adsorbed cells and that the $K_{\mathrm{s}}$ value for adsorbed cells increases with the increase in the amount of adsorbed cells. Reciprocal plots of $\mu_{\mathrm{a}}$ against $S$ (Fig. 6) resemble a relationship between $\mu$ and the concentration of a growth inhibitor in the case of a competitive type of inhibition, suggesting that there is competition for substrate uptake between adsorbed cells.

From these results, a model for bacterial growth in a heterogeneous system may be depicted. Cells of $E$. coli are adsorbed or resin surface in a monolayer as shown previously by electron microscopic observation (10), and cell density per unit surface area is estimated to be about $2-9 \times 10^{7}$ cells $/ \mathrm{cm}^{2}(6)$. Because of the high density of growing cells on resin surface, the rate of consumption of glucose by adsorbed cells may exceed the rate of diffusion to resin surface and substrate concentration in the vicinity of adsorbed cells may become much lower than that expected from bulk concentration, giving extremely high $K_{\mathrm{s}}$ values for the growth of adsorbed cells. When a large number of cell-loaded resin particles are packed in a small unit volume of culture, though each particle can move about in the culture medium with rotatory flow, diffusion of substrate through resin particles will often be disturbed and its supply for adsorbed cells may become much more limited, which will result in competition for a limiting substrate between adsorbed cells. Such a marked difference in response to a substrate between free and adsorbed cells may be a characteristic feature of this type of heterogeneous culture.

Previously, one of the authors reported that, in the case of glucose oxidation 
by resting cells of $E$. coli, the relation between $\mathrm{O}_{2}$ uptake rate and glucose concentration was nearly the same with free and adsorbed cells (11). This result indicates that there is no difference in $K_{\mathrm{s}}$ values for glucose uptake between free and adsorbed cells. The apparent inconsistency with the present report may be interpreted as follows. In the case of resting cells, rate of uptake of $\mathrm{O}_{2}$ by $10^{9}$ cells adsorbed on the same resin was $5 \mu \mathrm{l} / \mathrm{hr}(11)$. From this value, the rate of uptake of glucose by adsorbed cells is estimated to be about $0.03 \times 10^{-6} \mathrm{~mole} / 10^{9}$ cells $/ \mathrm{hr}$ assuming complete oxidation of glucose. On the other hand, in the case of growing cells in the rapid continuous flow culture, the rate of uptake of glucose by adsorbed cells is estimated from several experiments to be about $5-50 \times 10^{-6} \mathrm{~mole} / \mathrm{mg}$ dry cells $/ \mathrm{hr}$ or $1-10 \times 10^{-6} \mathrm{~mole} / 10^{9}$ cells $/ \mathrm{hr}$ assuming that $1 \mathrm{mg}$ dry weight of cells gives about $5 \times 10^{9}$ cells. The much higher glucose uptake rate with growing cells than that with resting cells thus may be the main cause for glucose-limited growth and for high $K_{\mathrm{s}}$ values with adsorbed cells in this experiment.

Although substrate concentration surrounding adsorbed cells is apt to be limited and their maximal growth rate is hardly realized, it is still notable that the value, $\mu_{\mathrm{a}}^{\max }$, is much higher than $\mu^{\mathrm{max}}$ as well as the fact that $Y_{\mathrm{a}}$ is much higher than $Y$, which may be related to the specific physiological effect of adsorption on the resin.

\section{REFERENCES}

1) D. H. LARSEN and R. L. Dimmick, J. Bacteriol., 88, 1380 (1964).

2) N. S. Panikov, I. V. Aseyeva, and I. K. Chistyakova, Microbiologia, 49, 794 (1980).

3) R. Hattori, J. Gen. Appl. Microbiol., 18, 319 (1972).

4) R. Hattori, J. Gen. Appl. Microbiol., 22, 215 (1976).

$5)$ R. Hattori, T. Hattori, and C. Furusaka, J. Gen. Appl. Microbiol., 18, 271 (1972).

6) T. Hattori and R. Hattori, CRC Critical Rev. Microbiol., 4, 423 (1976).

7) H. W. JANNASCH, J. Bacteriol., 99, 156 (1969).

8) D. Herbert, R. Elsworth, and R. C. Telling, J. Gen. Microbiol., 14, 601 (1956).

9) D. W. Tempest, In Methods in Microbiology, ed. by J. R. Norris and D. W. Ribbons, Academic Press, London and New York (1970), p. 259.

10) R. Hattori, T. Hattori, and C. Furusaka, J. Gen. Appl. Microbiol., 18, 285 (1972).

11) T. Hattori and C. Furusaka, J. Biochem., 48, 831 (1960). 